\title{
Moderasi al-Qur'an dan Penafsiran Kontemporer: Analisis Pemikiran Wahbah Zuhaili dan Relevansinya dalam Konteks Indonesia Modern
}

\author{
Mabrur \\ Dosen Universitas Azzahra Jakarta \\ emailmabroer_uinjkt@yahoo.com \\ hp 081320115319
}

\begin{abstract}
Abstrak: ini memaparkan bahwa Wahbah Zuhaili adalah mufassir kontemporer yang mengusung semangat al-Qur'an yang moderat (washatiyyah) dalam konteks kehidupan modern. Indikasi-indikasi dibuktikan dengan penafsirannya terhadap ayat-ayat yang terkait tentang relasi antar umat dan kebebasan beragama dalam menjalankan ajaran agamanya masing-masing dengan mengedepankan nilai-nilai hak dasar manusia dibandingkan aspek teologis-normatif dan menghindari segala bentuk polemik yang terkait dengan perbedaan manusia. Pandangan itu pula, sejalan dengan prinsip kehidupan konteks Indonesia modern di bawah asas Pancasila.

Untuk mengkaji pemikiran demikian, penulis merujuk pada kitab tafsirnya sebagai sumber utama yaitu Tafsîr al-Munîr: Fî al-Aqîdah wa al-Sharîah wa al-Manhaj, dengan tiga karya lainnya yaitu, $H$ \{aqqu al-H\{urriyah fî al-Âlam, Tafsîr al-Wasit \{ Athar al-H\{arb Dirâsatan Fiqhiyyatan Muqâranatan dan buku-buku lainnya yang dapat mendukung penjelasan makalah ini.

Adapun langkah yang digunakan dengan menggunakan data-data kepustakaan (library research) yang bersifat deskriptif analitis, yaitu sebuah penelitian yang memberikan gambaran secara deskriptif dengan menggali secara mendalam yang terkait dengan pola penafsiran atau metode penafsiran yang digunakan oleh Wahbah Zuhaili. Pendekatan yang digunakan adalah pendekatan interpretasi (interpretatif aproach) dengan memahami pemikiran seorang tokoh/mufassir yang terdapat dalam karya-karyanya. Analisis ilmu tafsir dan komparatif juga tidak terlepas untuk memahami secara konprehensif pemikiran Wahbah Zuhaili.
\end{abstract}

Kata Kunci: al-Qur'an, Toleransi, Wahbah Zuhaili, Indonesia 


\section{A. Seputar Toleransi}

Term toleransi yang digunakan di dalam bahasa Arab adalah al-tasâmuh\{ berarti memudahkan sesuatu di dalamnya. ${ }^{1}$ Kata tasâmuh\{ adalah dasar kata dari samh\{un, samuh\{a yang berarti jayyidun yang baik atau indah. Kata ini pula membentuk makna al-jud yaitu sikap pemurah atau dermawan. ${ }^{2}$ Dengan demikian, toleransi memberi rangkaian makna untuk saling memudahkan satu sama lain dengan sikap terbuka dan kerelaan hati. Sikap saling terbuka dengan orang lain karena perbedaan dengan kerelaam diri terhadap orang lain. Akan tetapi, dalam al-Qur'an term tasâmuh\{ yang berkaitan dengan makna toleransi, al-Qur'an tidak mengemukakan sekalipun, akan tetapi dasar filosofis atau prinsip tentang kebebasan, kesetaraan dan yang terkait dengannya al-Qur'an banyak menyinggung demikian. Jika merujuk pada sebuah riwayat Nabi menegaskan tentang esensi agama Islam sebagai agama yang mengajarkan sikap toleran dan lurus.

Dengan demikian, sikap toleransi adalah kesadaran dan dorongan jiwa untuk menghargai dan menerima perbedaan tanpa ada sikap intervensi dengan pandangan dan sikap orang lain. Oleh karena itu, di dalam sikap toleransi ada muatan sikap memberikan kebebasan terhadap orang lain, dalam hal relasi hubungan antar umat beragama, ada sikap kesadaran bahwa manusia punya nilai kesetaran dan aspek-aspek keadilan menjadi pilar penting dalam kehidupan sosial masyarakat. Aspek demikian menjadi uraian penulis berikutnya untuk mengukur dan menilai muatan-muatan dalam prinsip-prinsip toleransi itu sendiri. Dalam istilah Abdul Moqsith al-Gazali menegaskan toleransi merupakan salah satu ajaran inti Islam yang sejajar dengan ajaran lain, seperti kasih, kebijaksanaan, kemashlahatan universal, keadilan. Pendeknya, prinsip-prinsip ajaran inti Islam itu bersifat trans-historis, trans-ideologis, bahkan trans-keyakinan agama. $^{3}$

Pada poin ini mendeskripsikan pemikiran Wahbah seputar toleransi terkait kebebasan dan relasi antar umat beragama. Untuk mengkaji demikian, penulis merujuk pada karya tafsirya Tafsîr al-Munî̀ $>r$ : $>\hat{\imath}$ al-Aqîdah wa alSharîah wa al-Manhaj serta beberapa karyanya dan mengutip beberapa pandangan mufassir lain untuk membandingkan dan memahami dinamika penafsirannya. Analisis ilmu-ilmu lain yang dapat memberikan penjelasan konprehensif dan mengukur arah pemikirannya juga akan digunakan dalam memahami kebebasan, kesetaraan atau persamaan. Untuk mengkaji demikian, maka perlu 394.

${ }^{1}$ Lawin Ma'lûf, al-Munjid fî al-Lugah (Beirut: al-Mat\}ba’ah al-Kauthaliyyah, 1956), hal,

${ }^{2}$ Ibn Manz\{hûr, Lisân al-AArab (Kairo: Dâr al-Hadîth, 2003), hal, 672-673.

${ }^{3}$ Abd Moqsith al-Gazali, Argumen Pluralisme Agama: Membangun Toleransi Berbasis alQur'an, (Depok: Kata Kita, 2009), hal, 215. 
menekankan perspektif yang digunakan dalam konteks relasi antar umat beragama dalam menempatkan kebebasan dan kesetaraan yaitu perspektif etika di antaranya, pertama, karena masalah hubungan sosial umat beragama itu sendiri masuk dalam wilayah kajian etika yaitu bagaimana sikap suatu umat beragama berhadapan dengan dengan atau memperlakukan umat yang lain berbeda agama. Kedua, dari segi studi etika sendiri, perspektif etika ini sangat penting karena akan dapat mengatasi berbagai pertimbangan, keputusan dan kepastian moral secara rasional dan obyektif. Ketiga, dan yang terpenting bahwa al-Qur'an sendiri merupakan kitab moral (pedoman etika) dari pada kitab teologi dan hukum. ${ }^{4}$

\section{B. Aplikasi Penafsiran Wahbah Zuhaili}

\section{Konsep Kebebasan Beragama dan Relasi Antar Umat Beragama}

Dalam pembahasan ini menentukan pola pemikiran Wahbah terkait bagaimana kebebasan beragama sebagai sebuah keniscayaan yang digambarkan di dalam al-Quran. Dari pandangan ini pula memberikan pemaparan bagaimana konsep agama bagi Wahbah apakah cenderung pada polarisasi ekslusif atau justru inklusif.? Sebab bagi sebagian kalangan kebebasan beragama dalam konteks ini bukan berarti setiap yang dilakukan dan dijalankan oleh penganut agama lain adalah benar. Namun, kebebasan dalam beragama dan menjalankan ajaran agama masing-masing sebagai sebuah pandangan bagaimana ajaran alQur'an memberikan kebebasan kepada manusia untuk memeluk dan menjalankan ajaran agamanya tanpa ada paksaan.

\section{a. Kebebasan Beragama}

Ayat yang menjadi legitimasi tentang kebebasan beragama adalah QS al-Baqarah [2] 256 sebagai berikut:

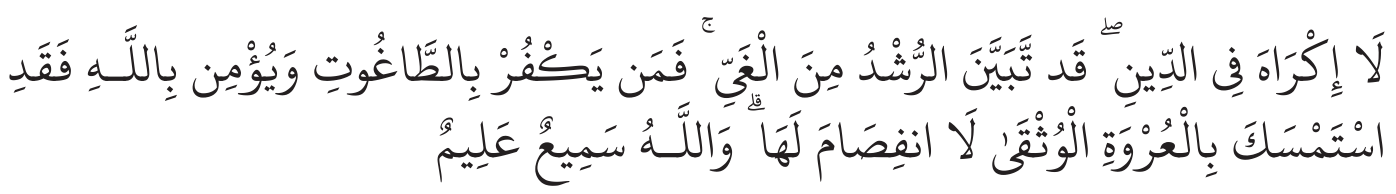

Tidak ada paksaan untuk (memasuki) agama (Islam); Sesungguhnya telah jelas jalan yang benar daripada jalan yang sesat. karena itu Barangsiapa yang ingkar kepada Thaghut dan beriman kepada Allah, Maka Sesungguhnya ia telah berpegang kepada buhul tali yang Amat kuat yang

${ }^{4}$ Hendar Riyadi, Melampaui Pluralisme: Etika al-Qur'an tentang Keragaman Agama (Jakarta: Graha Pena Jakarta. 2007), hal, 31. 
tidak akan putus. dan Allah Maha mendengar lagi Maha mengetahui (QS al-Baqarah [2] 256).

Dalam ayat ini Wahbah memberikan sebuah kesimpulan bahwa konteksnya berbicara tentang larangan memaksa dalam beragama, sebab agama merupakan landasan iman sebagai bagian dari hidayah dan otoritasnya ada pada Tuhan. ${ }^{5}$ Subtansi ayat ini mengutarakan tiga hal yaitu [1] larangan memaksa untuk memeluk agama, [2] adanya koridor dan aturan yang telah diberikan oleh Tuhan, dan [3] konsekuensi dari kebebasan dalam memilih dan meyakini sebuah agama.

Cerminan sikap toleransi dalam memberikan kebebasan beragama terhadap orang lain ketika Tuhan menegaskan lâ ikrâha fî al-dîn (tidak ada paksaan untuk memasuki agama [Islam]) yang berarti tidak ada paksaan memasuki dan memeluk sebuah agama. ${ }^{6}$ Agama bagi Wahbah dalam konteks ini adalah ekspresi kepercayaan hati dan agama (millah) sebagai sebuah ajaran. ${ }^{7}$ Oleh karena itu, kebebasan dengan tanpa ada paksaan terhadap orang lain untuk memeluk dan meyakini Islam didasarkan penegasan Tuhan (sesungguhnya telah jelas jalan yang benar daripada jalan yang sesat) sebagai sebuah indikasi Tuhan memberikan ultimatum bahwa kebebasan yang diberikan-Nya punya konsekuensi logis yang harus diterima. Maka ultimatum yang sangat jelas antara jalan yang baik dan buruk sebagai sebuah indikasi bahwa keyakinan adalah sifatnya petunjuk sedangkan kekufuran adalah bentuk kesesatan, dan bentuk kesesatan merupakan sebuah kebodohan. ${ }^{8}$

Dari sini, Wahbah meyakini kebebasan manusia untuk memilih agama sebagai ekspresi keyakinan merupakan hak otoritas Tuhan sebagai bimbingan 3, hal, 18.

${ }^{5}$ Wahbah al-Zuh\{\{ailî, Tafsîr al-Munî>r: F>î al-Aqîdah wa al-Sharîah wa al-Manhaj, vol,

${ }^{6}$ Kata al-Dîn dalam bentuk ma’rifah sebagian besar ulama menafsirkannya dengan agama Islam, sebab konteks ayat ini berbicara terkait tidak ada paksaan kepada seseorang untuk memeluk agama Islam ketika telah jelas jalan yang benar dan salah yang telah di gariskan oleh Allah. Abdu al-H\{ayy al-Farmâwî, al-Sahl al-Mufîd fî Tafsîri al-Qurâni al-Majîdi (Beirut: Dâr al-Mảrifah, 2009), vol i, hal, 114.

${ }^{7}$ Dalam konteks ini Wahbah memahami sebagai sebuah keyakinan dan agama. Bebeberapa term millah dikaitkaan dengan Ibrahim sebagai simbol bapak agama samawi. Millah Ibrahim sebagai agama yang h \{anîf (lurus) yaitu ajaran agama yang yang cenderung jauh dari kebathilan dan mengarah kepada kebaikan. Mengikuti ajaran agama (millah) sebagai sebuah ajaran yang diterima Ibrahim di mana kondisi dan sifatnya secara subtansial. Lihat al-Râzi, Mafâtîh al-Gaib, vol, iv, hal, 155. Lihat pula Wahbah al-Zuh\{\{ailî, Tafsîr al-Munî>r: F>î al-Aqî̉dah wa al-Sharîah wa al-Manhaj, vol i, hal, 317. iii, hal, 19.

${ }^{8}$ Wahbah al-Zuh\{\{ailî, Tafsîr al-Munî>r: F>î al-'Aqîdah wa al-Sharîah wa al-Manhaj, vol 
dan petunjuk. ${ }^{9}$ Berangkat dari anggapan demikian, Wahbah meyakini ajaran agama Islam tidak didasari atas dasar kekerasan dengan pedang, sebab Islam didasarkan sebagai agama yang memberikan petunjuk bukan jalan kesesatan, sehingga agama sifatnya menjadi sebuah nilai kebenaran berdasarkan keyakinan, dan tidak akan merasakan kebenaran (Islam) jika atas dasar paksaan. ${ }^{10}$ Alasan lain yang sangat filosofis bagi Wahbah adalah kebebasan itu sifatnya alamiah merupakan bawaan manusia yang diberikan oleh Tuhan, sehingga manusia dilahirkan dalam keadaan merdeka. Argumentasi ini menunjukkan kebebasan tidak hanya merupakan hak bahkan menjadi sebuah kewajiban yang secara nyata yang dititipkan oleh Tuhan. ${ }^{11}$

Pandangan yang senada dengan Thabathaba'i bahwa ajaran agama Islam menafikan sikap paksaan untuk meyakini ajaran Islam, sebab agama ${ }^{12}$ sebuah dasar pengetahuan dan pengalaman manusia yang menjadi sebuah acuan sehingga menjadi kepercayaan. Oleh karena memeluk agama sebagai ekspresi kepercayaan dan pengetahuan manusia, maka ia tidak dapat dihakimi dengan sikap memaksa karena akan berdampak terhadap segala bentuk tindakan dan sikap keagamaannya. ${ }^{13}$

Gambaran demikian, Wahbah mengapresiasi tentang kebebasan untuk memeluk agama Islam dalam konteks ini tanpa ada paksaan. Namun, atas dasar ayat ini, bukan berarti kebebasan memeluk sebuah agama Wahbah meyakini itu sebagai sebuah kebenaran, melainkan memeluk agama dinilai sebuah petunjuk

${ }^{9}$ Senada yang dikemukakan Jawdat Sa'îd dalam konteks ayat ini mendiskusikan beberapa persoalan [1] Ayat ini memberi jaminan kebebasan tanpa ada sikap paksaan termasuk dalam urusan agama. [2] redaksi ayat ini memungkinkan dua hal apakah bentuk kalimat perintah (kalimat inshầi) atau kalimat informatif (kalimat khabari), sehingga redaksi makna ini bentuk perintah untuk tidak memaksa orang lain dalam hal urusan agama, atau memberikan informasi bahwa seseorang yang memeluk ajaran Islam karena paksaan bukanlah sejatinya bentuk keyakinan melainkan sebatas ucapan saja. Lihat Jawdat Sa’îd, Lâ Ikrâha fî al-Dîn: Dirâsatan wa Abhâth fî al-Fikr al-Islâmi (Beirut: Dâr al-Kutub al-Ilmiyyah, 1999), hal, 26-35.

${ }^{10}$ Wahbah al-Zuh\{\{ailî, Tafsîr al-Munî>r: F>î al-Aqîdah wa al-Sharîah wa al-Manhaj, vol iii, hal, 21.

${ }^{11}$ Wahbah Zuhaili, H\{uqûq al-H\{urriyah fî al-Âlam, terj: Ahmad Minan (Jakarta: Pustaka al-Kautsar, 2005), hal, 6-7.

${ }^{12}$ Toleransi Islam atas kebebasan orang lain untuk memilih agama dan menjalankannya sebagai gagasan mendasar Islam bahwa sikap paksaan dan kekerasan Islam tidak mengakomodir demikian. Sebab, apa yang dipercayai oleh seseorang adalah dasar ekpsresi mengetahui dan meyakini bahkan pengalaman pribadinya. Untuk itu, berbicara agama tidak hanya dibatasi pada sebatas ajaran, melainkan agama juga sebagai aneka kepercayaan, terlepas apakah itu dinilai oleh sementara ulama pakar sebagai telah memenuhi syarat untuk dinamai agama atau tidak. Karena agama sejalan dengan penggunaan kata al-din dalam al-Qur'an. Lihat Quraish Shihab, Membaca Sirah Nabi Muhammad Saw: Dalam Sorotan al-Qur'an dan Hadits-hadits Shahih (Ciputat: Lentera Hati, 2011), hal, 381-382.

13 H\{usein T\{abat\{abâ’i, al-Mizân fî Tafsîr al-Qur’ân (Teheran: Dâr al-Kutub al-Islâmiyyah, t,th), vol ii, hal, 360-361. 
dan otoritasnya ada pada Tuhan. Untuk itu, Islam sebagai sebuah petunjuk hidup telah dibangun dan diberikan jalan hak dan bathil kepada manusia, maka hak kebebasan memilih inilah al-Qur'an memberikan komitmen kepada manusia untuk menentukan dan memilih agama sebagaimana pada QS al-Kahfi 29:

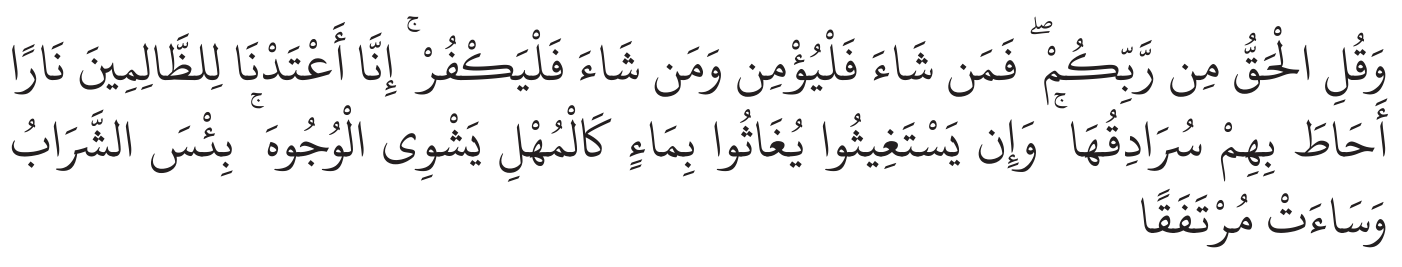

Dan Katakanlah: "Kebenaran itu datangnya dari Tuhanmu; Maka Barangsiapa yang ingin (beriman) hendaklah ia beriman, dan Barangsiapa yang ingin (kafir) Biarlah ia kafir". Sesungguhnya Kami telah sediakan bagi orang orang zalim itu neraka, yang gejolaknya mengepung mereka. dan jika mereka meminta minum, niscaya mereka akan diberi minum dengan air seperti besi yang mendidih yang menghanguskan muka. Itulah minuman yang paling buruk dan tempat istirahat yang paling jelek. (QS al-Kahfi [18] 29).

Pandangan demikian, Wahbah secara tersirat tidak mengakui pluralisme $^{14}$ agama dalam konteks semua agama sama sehingga pemeluk agama semua berhak mendapatkan keselamatan. ${ }^{15}$ Sebab, konteks kebebasan beragama bukan berarti memberikan justifikasi bahwa di luar agama Islam yang menjadi keyakinan seseorang dapat di anggap benar, hanya pada sikap penekanan memberikan toleransi kepada manusia untuk tidak memaksa orang lain memeluk Islam, dengan alasan konkrit bahwa telah jelas ajaran dan tuntunan yang diberikan oleh Tuhan. Dasar pemikiran Wahbah ini sejalan dengan Husein Fadhlullah bahwa pada dasarnya Islam sebagai sebuah agama fit\}rah (suci) dalam aspek ketentuan ekspresi keyakinan kepada Allah dan segala bentuk perintah dan larangannya,

${ }^{14}$ Jika merumuskan pada defenisi John Hick bahwa pluralisme agama adalah suatu gagasan bahwa agama-agama besar dunia merupakan persepsi dan konsepsi yang berbeda tentang, dan secara bertepatan merupakan respon yang beragam terhadap Yang Real atau Yang Maha Agung dari dalam pranata kultural manusia yang bervariasi, dan bahwa transformasi wujud manusia dari pemusatan diri menuju pemusatan hakikat terjadi secara nyata dalam setiap masing-masing pranata kultural manusia tersebut dan terjadi sejauh yang dapat di amati sampai pada batas yang sama. Pandangan John Hick ini ingin menegaskan bahwa sejatinya semua agama adalah merupakan manifestasi-manifestasi dari realitas yang satu, maka semua agama sama dan tak ada yang lebih baik dari yang lain. Anis Malik Thoha, Tren Pluralisme Agama: Tinjauan Kritis (Jakarta: Perspektif, 2005), hal, 15.

${ }^{15}$ Lihat penafsiran Wahbah Zuhaili QS al-Baqarah [2] 62. 
bahkan konsep kebebasan beragama sebagai sebuah penegasan Tuhan bahwa yang tak bisa di elakkan karena pluralitas agama. ${ }^{16}$

Atas dasar ini pula Wahbah menegaskan kembali kebenaran sesungguhnya hanya berasal dari Allah, tanpa ada unsur keraguan di dalamnya berdasarkan ajaran yang di bawa Nabi Saw, sehingga secara ekslusif Wahbah tegaskan, kehendak untuk mempercayai dan memeluk Islam akan berdampak pada pola kehidupan yang aman, ${ }^{17}$ sehingga penegasan Tuhan sebagai sebuah ancaman atas bentuk pilihan manusia dalam meyakini sebuah agama. ${ }^{18}$ Karena itulah segala bentuk tindakan dan kebebasan manusia akan berdampak terhadap dirinya sendiri, dalam konteks memilih keyakinan dan agama juga demikian, di mana atas dasar keyakinan seseorang orang lain tidak dapat menjustifikasi karena sifatnya personal kecuali dirinya sendiri. ${ }^{19}$

\section{b. Kebebasan Menjalankan Ajaran Agama Masing-masing ${ }^{20}$}

Penjelasan sebelumnya mempertegas bahwa al-Qur'an memberi legitimasi tentang kebebasan beragama sebagai implikasi dari pluralitas kehidupan manusia. Kebebasan demikian tidak hanya sebatas toleransi al-Qur'an terhadap manusia untuk meyakini agama tertentu, melainkan mereka juga berhak menjalankan ajaran berdasarkan keyakinannya masing-masing. Toleransi yang ingin dibangun Islam adalah sikap saling memghormati antar pemeluk agama yang berlainan tanpa mencampurkan akidah. Sebagaimana yang dikemukakan Yusuf al-Qaradhawi bahwa di antara nilai-nilai kemanusiaan yang juga sangat diperhatikan oleh Islam adalah kebebasan. Kebebasan meliputi kebebasan beragama, berpikir, berpolitik, dan segala bentuk kebebasan dalam kebenaran. ${ }^{21}$ Persoalan akidah adalah sesuatu yang paling mendasar dalam setiap agama sehingga bu-

${ }^{16} \mathrm{H}\{$ usein Fad\{lullâh, Min Wah>yi al-Qur'ân (Beirut; Dâr al-Malk, 1998), hal, 46-47.

${ }^{17}$ Ekslusifitas Wahbah dalam memahami Islam sebagai sebuah agama dan ajaran yang paling sempurna terlihat ketika memahami (QS Ali Imran [3] 19 dan 85) di mana dalam ayat ini mengukuhkan supremasi Islam sebagai sebuah agama dibanding dengan agama-agama lain. Islam bagi Wahbah adalah agama yang sempurna, di dalamnya mengajarkan ketauhidan, keselamatan, keadilan dan segala sesuatunya. Maka mereka yang memeluk agama selain Islam maka dianggap tidak benar dan ditolak. Wahbah al-Zuh\{\{ailî, Tafsîr al-Munî>r: F>î al-Aqîdah wa al-Sharîah wa al-Manhaj , vol 3, hal, 179-181.

${ }^{18}$ Wahbah al-Zuh\{\{ailî, Tafsîr al-Munî>r: F>î al-'Aqîdah wa al-Sharîah wa al-Manhaj ,vol 15, hal, 242-243.

${ }^{19}$ Shadiq al-Nayhoum, Islâm D $\{$ id al-Islâm (London: United Kingdom, 1994), hal, 242. Wahbah al-Zuh\{\{ailî, Tafsîr al-Munî>r: F>î al-'Aqîdah wa al-Sharîah wa al-Manhaj, vol 15, hal, 242.

${ }^{20}$ Wahbah al-Zuh\{\{ailî, Tafsîr al-Munî>r: F>î al-Aqî̉ah wa al-Sharîah wa al-Manhaj, vol, 30, hal, 215-216.

${ }^{21}$ Yûsuf Qarad\{âwî, Malâmih al-Mujtama’ al-Muslim terj: Abdus Salam Masykur, (Solo: Era Intermedia, 2004), hal, 155. 
kan wilayah untuk mencampuradukkan akidah masing-masing. ${ }^{22}$ Perwujudan toleransi dalam kerukunan antar umat beragama dapat direalisasikan dengan dua cara. Pertama, setiap penganut agama mengakui eksistensi agama-agama lain dan menghormati segala hak asasi penganutnya. Kedua, dalam pergaulan bermasyarakat setiap golongan umat beragama menampakkan sikap saling menghormati, menghormati dan menghargai. ${ }^{23} \mathrm{Hal}$ ini ditegaskan dalam QS al-Kâfirûn [109] 1-6:

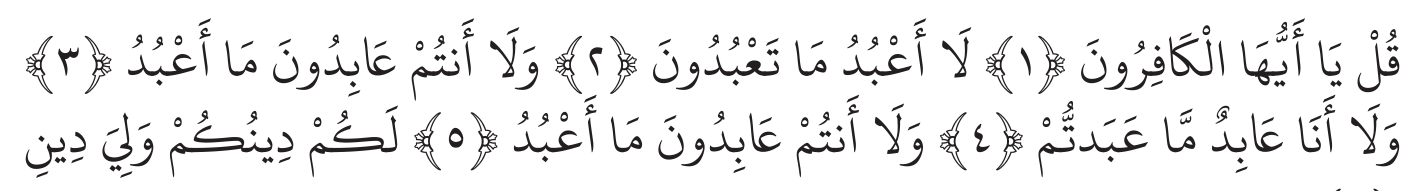

Katakanlah: «hai orang-orang kafir, aku tidak akan menyembah apa yang kamu sembah, dan kamu bukan penyembah Tuhan yang aku sembah. dan aku tidak pernah menjadi penyembah apa yang kamu sembah. dan kamu tidak pernah (pula) menjadi penyembah Tuhan yang aku sembah. untukmu agamamu, dan untukkulah, agamaku.(QS al-Kâfirûn [109] 1-6).

Ayat ini turun pada fase Makkiyah di mana sebab yang melatar belakangi berkaitan dengan tokoh Quraisy Mekkah diantaranya adalah Umayyah bin Khalaf dan al-Walid bin al-Mugirah untuk menegosiasikan kepada Nabi saw terkait tuntunan agama. Mereka memberikan usulan kepada Nabi saw untuk mengikuti ajaran mereka dan mereka akan mengikuti ajaran Nabi saw dengan cara kami akan menyembah Tuhan mu wahai Muhammad selama setahun dan kamu juga menyembah tuhan kami setahun pula. Dengan demikian, kalau agamamu Muhammad benar, kami akan mendapatkan keuntungan, sebaliknya jika agama kami benar, kamu (Muhammad) akan mendapatkan keuntungan pula. Mendengar ucapa mereka, Nabi saw langsung berlindung kepada Allah, maka ayat ini turun. ${ }^{24}$

Subtansi dari ayat ini adalah berbicara tentang loyalitas dan keikhlasan beragama dengan menjalankan prinsip ajaran masing-masing dan memberikan kebebasan kepada orang lain untuk menjalankan ajarannya. Penegasan ini berdasar kepada Qul Yâ Ayyuhâ al-Kâfirûn lâ A'budu mâ Ta'budûn (Katakanlah [Muhammad] hai orang-orang kafir, saya tidak akan menyembah apa yang ka-

${ }^{22}$ Kementerian Agama, Hubungan Antar Umat Beragam Tafsir Temati al-Qur’an, hal, 40.

${ }^{23}$ Said Agil Husin al-Munawar, Fikih Hubungan Antar Umat Beragama (Ciputat: Ciputat Press, 2003), hal, 17.

${ }^{24}$ Wahbah al-Zuh\{\{ailî, Tafsîr al-Munî>r: F>î al-'Aqîdah wa al-Sharîah wa al-Manhaj, vol , 29, hal, 439. 
lian sembah). Yang berarti seruan Allah kepada Nabi saw untuk mempertegas kepada kafir Quraisy bahwa tidak akan menyembah segala yang mereka sembah apapun bentuknya. Dalam konteks ini pula perintah Allah kepada Nabi saw dengan Qul (katakanlah) sebagai bentuk perintah kepada Nabi saw untuk berlemah lembut dalam segala bentuk persoalan dengan cara bertutur kata yang baik dan lembut terhadap segala persoalan. ${ }^{25}$ Indikasi demikian, menegasikan bahwa Islam menekankan sikap terbuka dengan keramahan dan santun untuk menghadapi berbagai persoalan. Dalam konteks ini pula Wahbah menegaskan bahwa menjalankan ajaran agama masing-masing terkait dengan masalah menjalankan prinsip keyakinan masing-masing tanpa mempengaruhi, memaksa dan mencampuradukkan atas keyakinan kita masing-masing dengan keyakinan orang lain. Sebab, subtasi utama dalam ayat ini adalah perintah untuk ikhlas dan tunduk dalam mengabdi kepada Allah sebagai bentuk loyalitas. ${ }^{26}$

Ketika ayat ini mengemukakan lakum dînukum waliya dîn (untukmu agamamu, untukku agamaku) problemnya, apakah ini berarti al-Qur'an membenarkan cara beragama orang lain di luar Islam ataukah hanya sebatas sikap toleransi untuk menyikapi keyakinan dan ajarang agama lain? Bagi Wahbah konteks ayat ini berbicara tentang toleransi terhadap umat beragama untuk menjalankan ajarannya masing-masing, bukan dalam hal Islam melegitimasi ajaran mereka (non muslin). Sebab (untukmu agamamu, untukku agamaku) berarti keyakinan dan ajaran kalian itu adalah hak otoritas masing-masing, akan tetapi sebagai umat Islam basis Islam adalah tauhid, keikhlasan dan kepasrahan. ${ }^{27}$ Pandangan ini dilatar belakangi bahwa konsep diluar keyakinan Islam adalah sebagai bentuk tindakan syirik sebagaimana yang dilakukan oleh kaum Quraisy. Maka konsekuensi dari agama adalah tindakan dan balasan, sehingga apa yang diyakini dan dilakukan oleh seseorang akan berdampak pada dirinya berdasarkan keyakinannya. Tentu dalam konteks ini Wahbah secara esklusif bahwa hanya Islam yang menjadi agama yang benar. ${ }^{28}$

Dengan demikian, penafsiran Wahbah terhadap ayat ini memposisikan pandangannya bahwa Islam mengapresiasi ajaran agama lain, namun tidak membenarkan konsep ajarannya. Sebab, dasar filosofis utama adalah Islam , 29, hal, 441.

${ }^{25}$ Wahbah al-Zuh\{\{ailî, Tafsîr al-Munî>r: F>î al-'Aqîdah wa al-Sharî̉ah wa al-Manhaj, vol

${ }^{26}$ Wah\{bah Zuh\{ailî, Tafsîr al-Wasît\{ (Beirut: Dâr al-Fikr, 1422 ), vol iii, 2946.

${ }^{27}$ Berbicara tauhid merupakan etika fundamental al-Qur'an yang menjadi dasar teologi Islam sekaligus mengajarkan wawasan kebinekaan keagamaan dan hubungan sosial antar umat beragama, sehingga impilkasi dari basis tauhid ini menciptakan tata sosial yang etis berlandaskan moral, egalitarian dan berkeadilan. Hendar Riyadi, Melampaui Pluralisme; Etika al-Qur'an tentang Keragaman Agama (Jakarta: Graha Pena Jakarta: 2007), hal, 121-122.

${ }^{28}$ Wahbah al-Zuh\{\{ailî, Tafsîr al-Munî>r: F>î al-'Aqîdah wa al-Sharîah wa al-Manhaj, vol , 29, hal, 443 . 
melarang segala bentuk kemusyrikan. Nampak pandangan ini sejalan dengan Mahmud Syaltut bahwa Islam menegaskan konsep ketauhidan yaitu konsep ulûhiyyah yang di dalamnya meliputi konsep tauhid rubûbiyyah yaitu tidak ada pencipta selain Dia, tidak yang berhak disembah selain Dia dan segala tempat permohonan. ${ }^{29}$

Konsep kebebasan beragama sebagai keniscayaan sehingga di pandang Wahbah perlu disikapi dengan sikap lemah lembut bukan dengan paksaan, dengan memberikan sikap toleran terhadap ajaran yang dilakukan oleh setiap pemeluk agama masing-masing tidak hanya berlandaskan pada ayat-ayat di atas yang sifatnya teologis. Melainkan kerangka filosofis-historis dengan merujuk pada piagam Madinah yang di anggap pondasi dasar Nabi saw meletakkan dasar kebebasan antara orang-orang Yahudi dengan ketiga kelompok lainnya untuk melaksanakan simbol-simbol keagamaan mereka, dalam piagam tersebut disebutkan sebagai berikut:

"Orang Yahudi dari Bani 'Auf merupakan satu umat bersama orang-orang mukmin. Bagi orang Yahudi adalah agama mereka dan bagi orang Islam adalah agama mereka, kecuali orang yang zhalim dan berdosa. Sesungguhnya ia tidak dirusakkan atau dibinasakan kecuali oleh dirinya sendiri dan keluarganya."30

\section{c. Relasi Antar Umat Beragama: Menghargai Keyakinan Agama Lain}

Penulis di awal telah mengemukakan tentang pluralitas sebagai sebuah keniscayaan membutuhkan sikap saling terbuka, saling menghargai, saling menghormati. Sikap inilah kemudian menjadi alasan subtansial Tuhan menghadirkan keberagaman salah satunya perbedaan keyakinan. Filosofi demikian yang menjadikan sikap toleran menjadi sangat penting untuk menumbuhkan harmonisasi dalam kehidupan masyarakat. Terkait dengan pluralitas agama ( $r e-$ ligious plurality) pada poin ini akan mengantarkan pada pandangan Wahbah untuk melihat responya terkait dengan relasi antar umat beragama dan bagaimana menyikapi dan merespon terhadap kebebasan mereka menjalankan ajarannya masing-masing tanpa menimbulkan rasa kebencian dan penghinaan terhadap pemeluk agama lain, sebab al-Qur'an mengakui pluralitas agama sebagaimana yang dikemukakan pada QS al-Baqarah 62

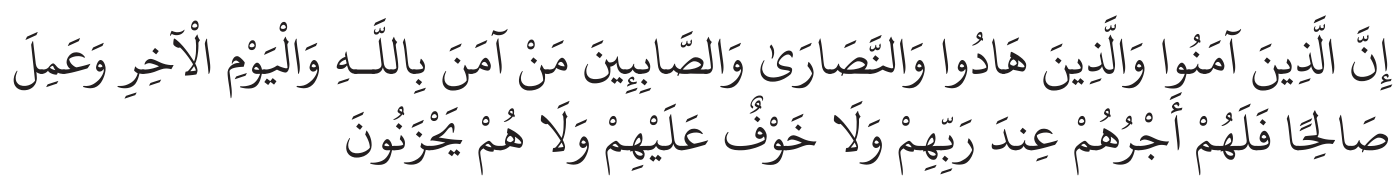

${ }^{29}$ Landasan teologisnya adalah QS al-Baqarah [2] 21-22, dan QS al-Isrâ [17) 42. Lihat $\operatorname{Mah}\{$ mûd Shaltût, al-Islâm Aqîdatun Wa Sharîatun (tt: Dâr al-Qalam, 1966), vol 3, hal, 29-30.

${ }^{30}$ Wahbah Zuh\{ailî, H\{aqqu al-Hurriyah fi al-'̂̂lam, hal, 148. 
Sesungguhnya orang-orang mukmin, orang-orang Yahudi, orang-orang Nasrani dan orang-orang Shabiin, siapa saja diantara mereka yang benarbenar beriman kepada Allah, hari kemudian dan beramal saleh, mereka akan menerima pahala dari Tuhan mereka, tidak ada kekhawatiran kepada mereka, dan tidak (pula) mereka bersedih hati. (QS al-Baqarah [2] 62)

Ayat ini menjadi "problematis: dikalangan ulama/pemikir Islam yang mengakui adanya pluralisme agama dalam arti keselamatan bagi pemeluk agama bukan hanya monopoli umat Islam saja, melainkan Yahudi, Nasrani dan Shabii'in merupakan pemeluk agama yang juga dijamin keselamatan dan jaminan balasan dengan penuh keyakinan dan menjalankan amalan shaleh. Menurut Ze'ev Maghen ayat ini jelas memberi pemaknaan yang berbeda secara komunitas antara Muslim (alladzîna âmanû) dengan Yahudi, Kristen dan Sabi'in (wa alladzîna hâdû wa al-nas\}ârâ wa al-s\}âbiînai), akan tetapi mereka diberikan jaminan/balasan surga jika saja mereka percaya pada Tuhan dan hari akhir dan melakukan yang benar. ${ }^{31}$ Di awal penegasnnya, Wahbah mempertegas ayat ini tidak di mansûkh (dihapus), akan tetapi, membatasi pada persoalan keimanan yang sesungguhnya bagi siapa saja yang beriman kepada Allah dan Nabi Saw. ${ }^{32}$ Namun, penulis menilai Wahbah dalam konteks ini menolak adanya pluralisme beragama. Indikasi ini diklaim dalam pandangannya posisi agama Islam ketika membenturkan dengan konsep toleransi, Wahbah hanya membatasi pada sikap menghargai eksistensi agama lain, namun bukan berarti Islam dan agama-agama yang lain adalah sama. Akan tetapi, Islam dipahami secara ekslusif bahwa hanya Islam yang menjadi satu-satunya agama yang benar dan diterima. Walau demikian, eksistensi agama-agama sebelumnya Wahbah meyakini demikian sebagai kelanjutan dan penyempurnaan kehadiran agama Islam. Jika merujuk pada pada pandangan Jerald F Dirks bahwa secara subtansial al-Qur'an mengajarkan kepada umat Muslim untuk mempercayai kebenaran Wahyu yang diturunkan kepada ahlu kitab sebelum Islam, yaitu wahyu yang diturunkan pada agama-agama yang memiliki relasi khusus dengan agama Islam yang disebut Abrahamic Faith atau Abarahamic Reiligious yaitu kepercayaan yang dibawa oleh Nabi Ibrahim as. ${ }^{33}$

Dalam ayat ini, persoalan ahli kitab antara Yahudi dan Nasrani tidak menjadi perdebatan, sebab secara faktual wanita mereka dapat dinikahi hingga

${ }^{31}$ Ze'ev Maghen, The Interaction between Islamic Law and Non-Muslims: Lakum Dīnukum wa-lìya Dīni, dalam jurnal Islamic Law and Society, Vol. 10, No. 3, 2003, hal, 268.

${ }^{32}$ Wahbah al-Zuh\{\{ailî, Tafsîr al-Munî>r: F>î al-'Aqîdah wa al-Sharî̉ah wa al-Manhaj, vol 1, hal, 178.

${ }^{33}$ Lihat Jerald F Dirks, Abrahamic Faiths: Titik Temu dan Titik Seteru Antara Islam, Kristen dan Yahudi, terj Santi Indra Astuti ( Jakarta: Serambi, 2006), hal, 29. 
pada penyembelihan hewannya, Akan tetapi, Wahbah menegaskan salah satu bentuk keselamatan yang ditawarkan dalam ayat ini adalah kepasrahan dan ketundukan sebagai dasar iman dengan menjalankan segala bentuk syariat ajaran agama, tanpa menyekutukan-Nya walaupun Yahudi dan Nasrani, Wahbah ingin menegaskan bahwa ekspresi beragama adalah refleksi kepercayaan terhadap segala yang dibawa oleh Nabi saw, maka itulah nilai keselamatan dan keberuntungan. ${ }^{34}$

Pandangan demikian, penulis menilai Wahbah hanya berbicara dalam konteks eksistensi pemeluk agama yang diberikan ruang sama untuk melakukan dan mengamalkan segala bentuk peribadatan dengan mendasarkan pada konsep keyakinan yang benar. Tentu keyakinan yang benar bagi Wahbah berdasarkan konsep ajaran Islam yaitu tidak menyekutukannya dan mengakui kenabian dan kerasulan Muhammad saw. ${ }^{35}$ Konsekuensi demikian, Yahudi, Nasrani dan Shabi'in jika mereka meyakini sebenar-benarnya, maka berdampak pada pemaknaan Yahudi, Nasrani dan Shabi'in sebagai identitas, bukan pemeluk agama Yahudi, Nasrani dan Shabi'in, namun keyakinanya berdasarkan ajaran Islam. Nampak sejalan dengan pandangan Abu Zahrah bahwa mereka (Yahudi, Nasrani dan Shabiin) jika berlandaskan iman yang benar yaitu meyakini sepenuhnya Allah, tidak menyekutukan, menyadari bahwa tidak ada sekutu baginya, tidak beranak dan diperanakkan maka mereka juga akan mendapatkan keselamatan. ${ }^{36}$

Eksistensi agama-agama lain tidak terbantahkan oleh al-Qur'an sendiri, sehingga hubungan antar sesama pemeluk agama mengandaikan sikap saling menghormati dan menghargai satu sama lain meskipun berbeda keyakinan bukan menjadi sebuah perpecahan, agama bagi kalangan sosiolog dianggap sebagai perekat dengan adanya ikatan emosional dan ikatan moral dari lapisan masyarakat yang menjaga nilai, kepercayaan dan kebiasaan yang dijaga bersama. ${ }^{37}$ Prinsip demikian menjadi salah satu misi yang ditegaskan dalam QS alAnîm [6] 108:

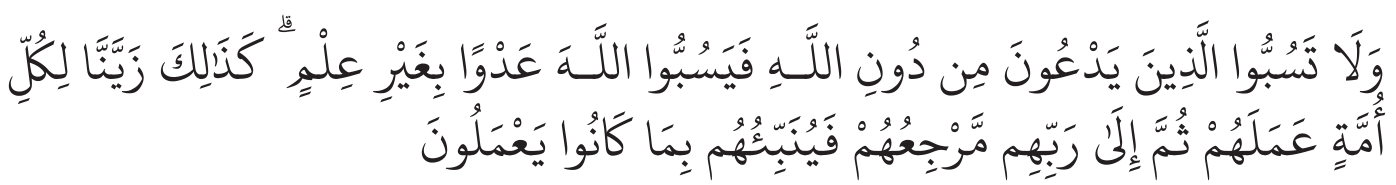
1, hal, 178.

${ }^{34}$ Wahbah al-Zuh\{\{ailî, Tafsîr al-Munî>r: F>î al-'Aqîdah wa al-Sharîah wa al-Manhaj, vol

${ }^{35}$ Wahbah al-Zuh\{\{ailî, Tafsîr al-Munî>r: F>î al-'Aqîdah wa al-Sharîah wa al-Manhaj, vol i, hal, 178.

${ }^{36}$ Muh\{ammad Abû Zahrah, Zahratu al-Tafâsir (Beirut: Dâr al-Fikr al-Arabiyy, tt), vol, 1, hal, 254 .

${ }^{37}$ Komaruddin Hidayat, Memahami Bahasa Agama: Sebuah Kajian Hermeneutika (Bandung: Mizan, 2003), hal, 272. 
Dan janganlah kamu memaki sembahan-sembahan yang mereka sembah selain Allah, karena mereka nanti akan memaki Allah dengan melampaui batas tanpa pengetahuan. Demikianlah Kami jadikan setiap umat menganggap baik pekerjaan mereka. kemudian kepada Tuhan merekalah kembali mereka, lalu Dia memberitakan kepada mereka apa yang dahulu mereka kerjakan. (QS al-An'âm [6] 108).

Ayat ini mengajarkan betapa pentingnya etika ataupun moral sesama pemeluk agama dan menjaga nilai mashalahat sesama pemeluk agama. Prinsip ini didasarkan larangan mencaci sembahan (tuhan) agama lain akan terjadinya disharmonis terhadap umat Islam dari agama lain. Berdasarkan kronologis ayat ini yang dikemukakan Wahbah sebagaimana yang dijelaskan Qatadah bahwa pada saat itu sahabat-sahabat Nabi saw mengolok-olok sembahan orang-orang musyrik berupa bintang-bintang, pepohonan dan lain-lain yang dapat menjerumuskan kemusyrikan, kejadian demikian al-Qur'an menegur agar tidak mencaci dengan alasan mereka akan mencela atau mengolok-olok kembali kepada Tuhan kalian (umat Islam). ${ }^{38}$ Alasan demikian Wahbah menilai perilaku dan tindakan menghina dan mencaci (tuhan) agama lain merupakan tindakan yang tidak sejalan dengan prinsip al-Qur'an. Argumentasi Wahbah lebih mengedepankan persoalan mashalat umat beragama terutama pada kubu umat Islam, hal ini ditegaskan walaupun sikap dan tindakan mencaci agama (tuhan) orang lain dan dapat mendatangkan mashlahat, tapi lebih besar mudharatnya, maka hal itu pun tidak dapat dilakukan..$^{39}$ Dengan mengutip pesan Ibn Abbas “janganlah hai orang-orang Muslim untuk menghina atau mencaci tuhan-tuhan orang-orang musyrik mereka yang menyembah selain Allah, ketika itu dapat menumbuhkan kebencian, hinaaan dan cacian mereka kepada Tuhanmu, sehingga dengan sikap dan tindakan karena kebodohan mereka dapat memancing sifat amarahmu kepada mereka"."

${ }^{38}$ Wah $\{$ bah Zuh\{ailî, Tafsîr al-Wasît \{, vol I, hal, 592-593.

${ }^{39}$ Hubungan menjaga relasi antar sesama pemeluk agama masing-masing merupakan bagian dari prinsip ajaran agama sebagai bentuk mashlahat. Imam al-Gazali menilai mashalat merupakan dasar atau pokok pembelajaran dengan mengambil sebuah manfaat dan menghindari segala sesuatu yang dapat merusak. Sebab, keduanya merupakan subtansi dari diciptakannya sesuatu dan menjadikan semuanya baik dengan menerapkan dua hal tersebut. Nah segala yang berkaitan mashalat merupakan tujuan dari syariat sedangkan misi dari syariat adalah memberikan kebaikan kepada makhluk, yaitu terjaganya lima prinsip dasar yaitu (agama, jiwa, akal, keturunan dan harta). Al-Gazali menegaskan kalau lima prinsip dasar ini terjaga, maka terealisasilah sebuah mashlahat, jutsru sebaliknya, jika lima prinsip demikian terabaikan maka itulah yang dianggap sebagai mafsadat (kerusakan). Abû H\{âmid al-Gazâli, al-Mus\{tashfâ (Beirut: Dâr al-Kutub 'Ilmiyyah, 1993), vol i, hal, 174.

${ }^{40}$ Wahbah al-Zuh\{\{ailî, Tafsîr al-Munî>r: F>î al-Aqîdah wa al-Sharîah wa al-Manhaj, vol 7, hal, 325-326. 
Pernyataan Ibn Abbas memberikan catatan penting bagi Wahbah sejatinya ketataan ataupun mashalahat yang dilakukan apabila menimbulkan kerusakan atau kebencian (mafsadat), maka tinggalkanlah. Sebab yang diharapkan dari sebuah kebaikan bukanlah kebencian, melainkan sifat lemah lembut dan kasih sayang, sebagaimana perintah Tuhan kepada Musa dan Harun untuk berlemah lembut dalam menghadapi Fira'un. ${ }^{41}$ Sedangkan menurut Nasir Sa'di mencaci sesembahan mereka yang dapat menjeremuskan pada kemusyrikan dalam melakukan ibadah dasar utama syariah membolehkan demikian, akan tetapi jika tindakan demikian dapat menimbulkan kerusakan dan permusuhan hendaknya tidak dilakukakn. ${ }^{42}$

Dari sini, dapat dilihat bahwa filosofis utama dalam setiap sikap, tindakan, perilaku hingga ideologi sebuah kelompok adalah mengedepankan nilai kemashalatan umum. Sebab, relasi kehidupan sosial Islam telah dibangun dengan dua konsep yaitu hubungan vertikal dan horizontal. Terkait hubungan horizontal (sesama manusia) menjadi sangat penting yang menjadi kemashlahatan umum dengan menumbuhkan sikap saling toleransi dalam pergaulan hidup antar umat beragama. ${ }^{43}$ Sebab Nabi saw di utus untuk mengajak manusia untuk melakukan kebaikan, saling tolong menolong, bahkan hubungan baik tidak hanya dibatasi pada kelompok tertentu, melainkan setiap manusia tanpa melihat status dan agamanya sekalipun. Karena Islam juga mengajak manusia untuk saling memuliakan dan menghargai dengan menjaga fitrahnya, kemuliannya dan kebebasannya sebagai manusia. ${ }^{44}$ Dengan demikian, Wahbah sejatinya menilai bentuk cacian dan hinaan terhadap se-sembahan orang lain, sebab sikap dan tindakan demikian dapat mendatangkan permusuhan dan kerusakan sehingga agama melarang, meskipun memberikan mashlahat, sehingga Wahbah memberikan toleransi terhadap pemeluk agama lain untuk saling menghargai satu sama lain. Namun Wahbah memberikan pengecualian, di mana bentuk cacian dan hinaan itu lebih memberikan mashalahat besar terhadap Islam, maka hal itu dapat dibenarkan. ${ }^{45}$

${ }^{41}$ Wahbah al-Zuh\{\{ailî, Tafsîr al-Munî>r: F>î al-'Aqîdah wa al-Sharî̉ah wa al-Manhaj, vol 7, hal, 326. Wahbah Zuh\{ailî, Tafsîr al-Wasith, vol I, hal, 592. Wahbah Zuh\{ailî, al-Wajîz fi Us\{ûl al-Fiqh (Beirut: Dâr al-Fikr al-Mu’âs\{ir, 1994), hal, 109. Penjelasan demikian berdasarkan QS T\{âha [20] 44: Maka berbicaralah kamu berdua kepadanya dengan kata-kata yang lemah lembut, Mudah-mudahan ia ingat atau takut". Menurut al-Husaini dialog yang baik dalam ayat ini dengan lemah lembut yang memberikan pemahaman dan tidak disertai dengan tindakan kasar. Lihat Ibn Lut\{fillâh al-H\{usaini, Fath\{u al-Bayân fi al-Maqâs\{idi al-Qurân (Beirut: Maktabah al-'Us\{riyyah, 1992), vol 8, hal, 235.

${ }^{42}$ Nâs\{ir Sa'di, Taisîr al-Karîm al-Rah\{mân fi al-Kalam al-Mannân (Beirut: Muassasah al-Risâlah, 2002), hal, 268-269.

${ }^{43}$ Said Agil Husin al-Munawar, Fikih Hubungan Antar Umat Beragama, hal, 14.

${ }^{44}$ Yûsuf al-Qarad\{âwi, Albâban Wa al-Islâm (Kairo: Maktabah Wahbah, 2007), hal, 51.

${ }^{45}$ Wahbah al-Zuh\{\{ailî, Tafsîr al-Munî>r: F>î al-'Aqîdah wa al-Sharîah wa al-Manhaj, vol, 7 , hal, 325 . 


\section{Relevansi Penafsiran Wahbah Zuhaili Dalam Konteks Indonesia Modern}

Penafsiran Wahbah yang penulis sajikan, menjadi perlu kiranya untuk memahami dan mengkajinya pada tataran konseptual dalam konteks kehidupan sosial keagamaan, Sebab, problem-problem sosial agama harus hadir untuk memberikan problem solving (penyelesaian masalah) tentu dengan pandangan dan ijtihad para ulama. Terkait toleransi antar umat beragama pada persoalan kebebasan beragama, menjalankan prinsip dan ajaran masing-masing dengan kesadaran pemikiran Wahbah perlu ditinjau dalam melihat dinamika keberagaman dewasa ini untuk menghadirkan Islam yang toleran. Sebagaimana yang dikutip Cak Nur bahwa kelebihan Islam atas agama-agama yang lain sebagai agama yang lapang atau kurang fanatik. ${ }^{46}$

Dinamika pemikiran Islam demikian, sangat menentukan pola dan perkembangan kehidupan umat manusia terkait dengan toleransi antar umat beragama dan eskistensi agama-agama. Sebab, penafsiran para ulama menjadi pola "konsumsi" masyarakat dalam menjalani realitas kehidupan. Tak terkecuali masyarakat modern yang dengan berbagai persoalan atau problem masyarakat yang membutuhkan kehadiran agama lewat ijtihad dan penafsiran ulama. Sebab, masyarakat modern sendiri yang sangat dinamis tak terelakkan dengan pergeseran nilai dan moral. Konsekuensi demikian, akan menimbulkan perubahan besar dibidang nilai, sikap dan kepribadian. Salah satu perubahan besar itu adalah bidang religi, sewaktu-waktu kepercayaan sekuler mulai menggantikan agama-agama tradisionalistis. ${ }^{47}$

Dalam konteks Indonesia, persoalan toleransi antar umat beragama menjadi keniscayaan atau kesadaran kolektif (collective consciousness) yang harus dihadirkan dan diciptakan dalam lingkup masyarakat. Menjadi catatan penting bahwa kehadiran Pancasila sebagai asas tunggal negara bukan "Islam" sebagai stimulan terhadap keberagaman atau pluralitas masyakat (suku, budaya dan agama) bahwa kebebasan dan kesetaraan terkait umat beragama menjadi hal yang tidak bisa dinafikan. Secara kenyataan haruslah disadari bahwa bangsa

\footnotetext{
${ }^{46}$ Nur Cholis Madjid, Islam Agama Peradaban: Membangun Makna dan Relevansi Doktrin Islam dalam Sejarah, hal, 59.

${ }^{47}$ Menurut Lerner ada 5 perubahan besar demikian selain pada bidang religi, yaitu, [1] dalam bidang politik, sewaktu-waktu sistem kewibawaan suku dan desa yang sederhana itu digantikan dengan sistem pemilihan umum, kepartaian, birokrasi dan lain-lain. [2] Dalam bidang pendidikan, sewaktu-waktu masyarakat berusaha mengurangi kebuta hurufan dan meningkatkan keterampilan-keterampilan yang membawa hasil-hasil ekonomi. [3] dalam lingkungan keluarga, ketika unit-unit hubungan kekeluargaan yang meluas menghilang, [4] dan lingkungan stratifikasi, ketika mobilitas geografis dan sosial cenderung untuk merenggangkan sistem-sistem hirarki yang sudah pasti dan turun temurun. Irfan Safruddin, Kritik Terhadap Modernisme (Jakarta: Ditjen Bimas Islam dan Penyelenggara Haji, 2005), hal, 126-127.
} 
Indonesia sejak awalnya adalah hidup dalam suasana kemajemukan, baik dilihat dari sudut etnis budaya maupun agama. Keragaman agama dan budaya menimbulkan dilema. Di satu sisi ia merupakan khazanah kekayaan bangsa, akan tetapi disisi lain dapat menjadi potensi konflik di kemudian hari, pada hal sisi universalitas dan subtansi agama tidak mengajarkan konflik. Oleh karena itu, beragama hendaknya dipandang sebagai suatu bentuk proses dialogis untuk mencari kebenaran, bukan hanya antar iman tetapi juga dengan sesama pemeluk agama. Absolutnya agama hanya terletak sewaktu ajaran agama masih merupakan wahyu yang terjewantahkan dalam akidah, ibadah dan nilai-nilai universal pada Islam yaitu keadilan, kesetaraan dan persaudaraan. ${ }^{48}$ Menurut Kuntowijoyo Islam adalah agama yang mengedepankan nilai-nilai universal dengan pandangan hidup mengenai persamaan, keadilan, kebebasan, kehormatan serta memiliki konsep teosentrisme yang humanistik dari seluruh ajaran Islam, dan karenanya menjadi tema peradaban Islam. ${ }^{49}$

Dalam kasus kebebasan memilih dan menjalankan ajaran masing-masing pemikiran Wahbah dipandang inklusif dengan menekankan manusia diberikan hak sepenuhnya oleh Tuhan dalam memilih dan menjalankan ajaran agamanya, maka memaksa orang lain untuk memeluk Islam tidak dapat dibenarkan secara teologis, sehingga indikasinya kebebasan memilih merupakan keniscayaan dalam realitas kehidupan masyarakat, yang berdampak pada perbedaan keyakinan dan agama. Oleh karena itu, sikap toleransi dengan menghargai keyakinan dan kebebasan orang lain sebuah sikap yang tidak bisa ditawar lagi demi kepentingan sosial hingga keberlangsungan beragama manusia.

Dalam konteks Indonesia sebagai masyarakat yang plural (agama, suku, bahasa, budaya dan lain-lain) menjadi sangat signifikan kontribusi pemikiran yang inklusif terhadap perbedaan. Sebab untuk mempertahankan dan menciptakan pluralisme sosial (masyarakat), perlu ada nilai-nilai toleransi, karena sikap toleransi tidak hanya berkaitan dengan legislasi, tetapi juga sikap sosial, bukan menghadirkan klaim kebenaran agama sendiri sehingga tidak mentolerir terhadap ajaran orang lain yang diyakini dan dijalankan, sehingga toleransi antar umat beragama membutuhkan kebesaran jiwa untuk menghargai dan menghormati atas ajaran orang lain, akan tetapi tetapi meyakini secara kuat keyakinan sendiri. Berkaitan dengan hal itu, pemerintah pada tahun (1977-1983) menerapkan kebijakan "trilogi kerukunan beragama", yaitu (1) toleransi antar suatu penganut agama tertentu, (2) toleransi antar penganut agama yang berbeda, (3) toleransi antar penganut agama dengan pemerintah. Untuk itu, setiap agama mempunyai hak dan kewajiban yang sama dengan memberikan fasilitas terhadap kegiatan

\footnotetext{
${ }^{48}$ Arifinsyah, "M Ridwan Lubis dan Kerukunan Antar Umat Beragam”, Harmoni, vol vi, no 23, Juli-September, 2007, hal, 175.

${ }^{49}$ Kuntowijoyo, Paradigma Islam (Yogyakarta: Mizan, 1991), hal, 229.
} 
penganut agama dalam hal ini Departemen Agama. Ini berarti bahwa Indonesia menerapkan pengertian toleransi yang positif. ${ }^{50}$

Konsep toleransi yang dikemukakan Wahbah hemat penulis, sebagai bentuk kesadaran terhadap realitas kehidupan masyarakat yang plural, sehingga dianggap sebagai keniscayaan sejarah, maka perbedaan sejatinya bukanlah kehendak mutlak manusia sendiri, melainkan Tuhan yang menghadirkan dan menginginkannya. Oleh karena itu, pandangan Wahbah lebih menekankan pada aspek sosial dan kemashlahatan untuk menghadirkan sikap beragama yang santun dan lemah lembut. Jadi, toleransi beragama dengan memberikan kebebasan terhadap orang lain untuk menjalankan ajarannya masing-masing upaya menghargai dan menghormati kehidupan beragama orang lain, bukan membenarkan atas ajaran orang lain. Asumsi penulis demikian, ditinjau pada kebenaran dan superioritas Islam dianggap lebih dari pada agama-agama lain, sehingga kebebasan dalam konteks ini bukan tanpa batasan melainkan dibatasi dengan nilai-nilai yang diatur dalam Islam yaitu persoalan tauhid. Maka secara tersirat Wahbah lebih mengapresiasi gagasan multikultural dan pluralisme masyarakat, di mana setiap orang atau kelompok berhak untuk tidak mendapatkan tekanan, hambatan, paksaan serta kekangan dari luar kita. ${ }^{51}$ Seseorang dikatakan bebas sejauh mana tidak ada orang atau kelompok yang ikut campur atas apa yang dilakukannya. Dalam konteks Indonesia, kita tidak hanya menemukan banyak agama, namun juga budaya dan bahasa. Dalam hal agama saja, rasanya amat mustahil mengasimilasikan beragam aliran atau madzhab ke dalam satu jenis aliran. ${ }^{52}$

Berbicara toleransi terkait relasi antar umat beragama tidak hanya sikap menekankan kebebasan orang lain untuk memilih dan mengekpresikan keberagamaannya. Lebih dari itu, upaya memberi keadilan atau kesetaran terhadap sesama pemeluk agama bagian yang tak terpisahkan sebagai bentuk kesadaran sosial. Menurut Cak Nur hakikat dasar kemanusiaan termasuk kemestiaan menegakkan kaedilan, merupakan bagian dari sunnatullâh, karena adanya fitrah manusia dari Allah dan perjanjian primordial antara manusia dan Allah. Karena sebagai sunnatullâh. Kemestian menegakkan keadilan adalah kemestian yang

${ }^{50}$ Masykuri Abdillah, Toleransi Beragama dalam Masyarakat Demokrasi dan Multikultural, dalam Konflik Komunal di Indonesia Saat Ini, (Jakarta: Pusat Bahasa dan Budaya UIN Jakarta, 2003), hal, 177-178.

${ }^{51}$ Kebebasan ini disebut sebagai kebebasan negatif. Sedangkan kebebasan postif bermakna bahwa seseorang atau kelompok bebas untuk merealisasikan dan mengejawantahkan dirinya sebagai kontrol serta penguasaan diri oleh rasionalitas. Ilham Mundzir, Negara, Hak-hak Minoritas dan Multikulturalisme ( Kasus Ahmadiyah), Indo-Islamika, vol 1, nomor 2, 2012, hal, 190.

${ }^{52}$ Ilham Mundzir, Negara, Hak-hak Minoritas dan Multikulturalisme ( Kasus Ahmadiyah), Indo-Islamika, hal, 190. 
merupakan hukum objektif, tidak tergantung kepada kemauan pribadi manusia siapapun juga..$^{53}$

Model pemikiran demikian, memberi dorongan dan arti penting dalam membangun masyarakat yang plural dalam komunitas masyarakat Indonesia. Berbicara pluralisme dan mulktikulturalisme tidak hanya mendiskusikan konsep dan teori semata, akan tetapi gagasan ini untuk mengilhami masyarakat guna menciptakan keadilan, kebebasan atau kesetaraan dalam berbagai perbedaan masyarakat di mana menghadapi tantangan global hingga persoalan demokrasi. Mengutip pandangan Robert Hefner dalam realitas kehidupan masyarakat modern demokratis dewasa ini, tidak ada ancaman yang lebih mengkhawatirkan bagi dunia modern mengenai kewarganegaraan demokratis dari pada terjadinya perpecahan etnis, religius yang kompleks dalam masyarakat. ${ }^{54}$

Penulis menilai, pada persoalan yang sifatnya relasi sosial tidak terkait dengan persoalan teologis, Wahbah secara terbuka atau inklusif menafsirkan demikian. Keragaman agama sebagai sebuah keniscayaan terkhusus dalam konteks Indonesia, bahwa pemeluk agama masing-masing berhak mengekspresikan ajaran agamanya dipandangan Wahbah sebagai kemestiaan dari ajaran mereka, bahkan semua pemeluk agama jika didasarkan pada keimanan yang tulus dalam menjalankan ajaran ibadahnya maka Tuhan akan memberikan ganjaran-Nya. Pemahaman pluralis yang ditunjukkan Wahbah menjadi salah satu kunci yang dapat menumbuhka kesadaran umat beragama, sebab memahami psikologis keberagamaan orang lain dapat membuka ruang toleran bagi sesama pemeluk agama. Pendek kata, konteks Indonesi modern meniscayakan pemikiran Islam yang inklusif yang menjunjung kesetaraan ataupun kebebasan. Menurut Asyumardi Azra masa depan Islam Indonesia yang moderat dan damai tergantung pada sikap adil, obyektif dan pro aktif dari mayoritas masyarakat moderat dalam merespon berbagai perkembangan yang terjadi dikalangan masyarakat Muslim Indonesia. ${ }^{55}$

\section{Kesimpulan}

Narasi al-Qur'an tentang moderasi Islam terkait dengan kebebasan dan relasi antar umat beragama menempatkan dan mempertegas posisi al-Qur'an sebagai hudan (petunjuk) bagi manusia. Kenyataan ini pula menegasikan al-

\footnotetext{
${ }^{53}$ Nur Cholis Madjid, Islam Agama Kemanusiaan: Membangun Tradisi dan Visi Baru Islam Indonesia (Jakarta: Paramadina, 2010), hal, 183.

${ }^{54}$ Robert W Hefner, Politik Multikulturalisme: Menggugat Realitas Kebangsaan (Yogyakarta: Kanisius, 200), hal, 11.

${ }^{55}$ Asyumardi Azra, Revisitasi Islam Politik dan Islam Kultural di Indonesia, Indo-Islamika, vol 1, nomor 2, 2012, hal, 242.
} 
Qur'an mengakomodir terhadap pluralitas sebagai sebuah keniscayaan, sehingga catatan penting dibalik toleransi yang dihadirkan al-Qur'an disebabkan. Pertama, Tuhan menghadirkan pluralitas dalam kehidupan manusia yang menjadi kehendaknya dengan tujuan untuk saling memahami, menghormati dan menghargai. Kedua, kebebasan beragama dan menjalankan ajaran agama menjadi hak prerogatif seseorang yang tidak bisa dipaksa, sebab agama merupakan pilihan sebagai sebuah ketulusan.

Epistemologis demikian, Wahbah memberikan catatan penting dibalik pemikirannya terkait toleransi sebagai berikut: Pertama, Ayat-ayat yang terkait dengan toleransi antar umat beragama dalam konteks kebebasan beragama, relasi antar umat beragama secara inklusif Wahbah memahaminya sebagai bentuk kebebasan manusia yang tidak bisa dipaksa ataupun diancam untuk memeluk ajaran Islam, sebab agama merupakan bentuk kesadaran murni ataupun ketulusan manusia. Dengan dibenarkannya kebebasan manusia memeluk agama tertentu tanpa dipaksa sebagai indikasi Islam sebagai agama yang mengajarkan sikap lemah lembut bukan dengan kekerasan. Kedua, toleransi terhadap sesama pemeluk agama, tidak menjadikan Wahbah membenarkan pilihan seseorang untuk memeluk agama lain (selain Islam), akan tetapi toleransi yang mengedepankan aspek etika bukan sifatnya teologis. Untuk itu, secara tersirat Wahbah menolak gagasan pluralisme yang mengakui keselamatan semua agama-agama. Ketiga, pandangan Wahbah dapat menjadi pijakan dalam konteks ke Indonesian untuk mengusung Islam yang ramah dan moderat dalam bingkai Pancasila

\section{Daftar Pustaka}

Abdillah, Masykuri. Toleransi Beragama dalam Masyarakat Demokrasi dan Multikultural, dalam Konflik Komunal di Indonesia Saat Ini, (Jakarta: Pusat Bahasa dan Budaya UIN Jakarta, 2003.

Abû, Muh\{ammad Zahrah. Zahratu al-Tafâsir. Beirut: Dâr al-Fikr al-Arabiyy, tt.

Agil, Said Husin al-Munawar. Fikih Hubungan Antar Umat Beragama. Ciputat: Ciputat Press, 2003.

al-H\{ayy, Abdu al-Farmâwî. al-Sahl al-Mufî̀ fî Tafsîri al-Qur'âni al-Majîdi. Beirut: Dâr al-Mảrifah, 2009.

Azra, Asyumardi. Revisitasi Islam Politik dan Islam Kultural di Indonesia, Indo-Islamika, vol 1, nomor 2, 2012.

Cholis, Nur Madjid. Islam Agama Kemanusiaan: Membangun Tradisi dan Visi Baru Islam Indonesia . Jakarta: Paramadina, 2010.

F, Jerald Dirks. Abrahamic Faiths: Titik Temu dan Titik Seteru Antara Islam, Kristen dan Yahudi, terj Santi Indra Astuti. Jakarta: Serambi, 2006. 
Fad\{lullâh, H\{usein. Min Wah>yi al-Qur'ân. Beirut; Dâr al-Malk, 1998.

H\{âmid, Abu al-Gazâli, al-Mus\{tashfâ . Beirut: Dâr al-Kutub 'Ilmiyyah, 1993.

Hidayat, Komaruddin. Memahami Bahasa Agama: Sebuah Kajian Hermeneutika . Bandung: Mizan, 2003.

Jawdat, Saî̀. Lâ Ikrâha fî al-Dîn: Dirâsatan wa Abhâth fî al-Fikr al-Islâmi. Beirut: Dâr al-Kutub al-Ilmiyyah, 1999.

Ma'lûf, Lawin. al-Munjid fî al-Lugah. Beirut: al-Mat\}ba'ah al-Kauthaliyyah, 1956.

Maghen, Zeev. The Interaction between Islamic Law and Non-Muslims: Lakum Dinukum wa-lìya Dìni, dalam jurnal Islamic Law and Society, Vol. 10, No. 3, 2003.

Malik, Anis Thoha. Tren Pluralisme Agama: Tinjauan Kritis \. Jakarta: Perspektif, 2005.

Manz\{hûr, Ibn. Lisân al-'Arab. Kairo: Dâr al-Hadîth, 2003.

Moqsith, Abd al-Gazali. Argumen Pluralisme Agama: Membangun Toleransi Berbasis al-Qur'an. Depok: Kata Kita, 2009.

Qarad\{âwî, Yûsuf. Malâmih al-Mujtama’ al-Muslim terj: Abdus Salam Masykur. Solo: Era Intermedia, 2004.

Riyadi, Hendar. Melampaui Pluralisme: Etika al-Quran tentang Keragaman Agama. Jakarta: Graha Pena Jakarta. 2007.

Sa'di, Nâs\{ir\. Taisîr al-Karîm al-Rah\{mân fi al-Kalam al-Mannân. Beirut: Muassasah al-Risâlah, 2002.

Safruddin, Irfan. Kritik Terhadap Modernisme. Jakarta: Ditjen Bimas Islam dan Penyelenggara Haji, 2005.

Shaltût, Mah\{mûd. al-Islâm Aqî̀atun Wa Sharîatun \. tt: Dâr al-Qalam, 1966.

Shihab, Quraish. Membaca Sirah Nabi Muhammad Saw: Dalam Sorotan alQuran dan Hadits-hadits Shahih. Ciputat: Lentera Hati, 2011.

T\{abat\{abầi, H\{usein. al-Mizân fî Tafsîr al-Qurân (Teheran: Dâr al-Kutub al-Islâmiyyah, $\mathrm{t}$,th.

W Hefner, Robert. Politik Multikulturalisme: Menggugat Realitas Kebangsaan. Yogyakarta: Kanisius, 2000.

Wahbah, Zuhaili. H\{uqûq al-H\{urriyah fî al-Âlam, terj: Ahmad Minan. Jakarta: Pustaka al-Kautsar, 2005. 